Conclusion: Our study revealed relationship of anti-Jo-1 and anti-Ro-52 but not anti-MDA-5 in ILD-inflammatory myopathies. Even though new autoantibodies panel give opportunity to a closer look for inflammatory myopathies, larger series of patients should be evaluated to determine the association of specific antibodies in the differential diagnosis and prediction of outcome of IIM. MSA positivity in non-IIM diagnosed patients should be monitored to determine whether this positivity is related to a future disease development.

Table 1: Frequency of MSAs and MAAs in idiopathic inflammatory myositis

\begin{tabular}{|c|c|c|c|}
\hline & $\begin{array}{l}\text { JDM/DM } \\
\text { (n=26 patients) }\end{array}$ & $\begin{array}{l}\text { PM/ASS } \\
\text { (n=35 patients) }\end{array}$ & $\begin{array}{l}\text { All } \\
\text { (n=61 patients) }\end{array}$ \\
\hline \multicolumn{4}{|c|}{ Myositis-specific autoantibodies, $\mathbf{n}(\%)$} \\
\hline Anti-Jo-1 & $1(3.8 \%)$ & $9(25.7 \%)$ & $10(16.4 \%)$ \\
\hline Anti-MDA-5 & $5(19.2 \%)$ & $3(8.6 \%)$ & $8(13.1 \%)$ \\
\hline Anti-SRP & $2(7.7 \%)$ & $4(11.4 \%)$ & $6(9.8 \%)$ \\
\hline Anti-TIF 1g & $4(15.4 \%)$ & $2(5.7 \%)$ & $6(9.8 \%)$ \\
\hline Anti-NXP2 & $4(15.4 \%)$ & $2(5.7 \%)$ & $6(9.8 \%)$ \\
\hline Anti-SAE1 & $2(7.7 \%)$ & $1(2.9 \%)$ & $3(4.9 \%)$ \\
\hline Anti-Mi-2 alpha & $2(7.7 \%)$ & $1(2.9 \%)$ & $3(4.9 \%)$ \\
\hline Anti-Mi-2 beta & $2(7.7 \%)$ & 0 & $2(3.3 \%)$ \\
\hline Anti-PL7 & 0 & $3(8.6 \%)$ & $3(4.9 \%)$ \\
\hline Anti-PL12 & 0 & $2(5.7 \%)$ & $2(3.3 \%)$ \\
\hline Anti-EJ & $1(3.8 \%)$ & $3(8.6 \%)$ & $4(6.6 \%)$ \\
\hline Anti-OJ & $1(3.8 \%)$ & 0 & $1(1.6 \%)$ \\
\hline \multicolumn{4}{|c|}{ Myositis-associated autoantibodies, $\mathbf{n}(\%)$} \\
\hline Anti-Ro-52 & $4(15.4 \%)$ & $16(45.7 \%)$ & $20(32.8 \%)$ \\
\hline Anti-PM-Scl 100 & $1(3.8 \%)$ & $4(11.4 \%)$ & $5 \quad(8.2 \%)$ \\
\hline Anti-PM-Scl 75 & $1(3.8 \%)$ & $4(11.4 \%)$ & $5(8.2 \%)$ \\
\hline Anti-Ku & 0 & $4(11.4 \%)$ & $4(6.6 \%)$ \\
\hline
\end{tabular}

Disclosure of Interests: Gözde Kübra Yardımcı: None declared, Enes Erul: None declared, Emre Bilgin: None declared, Bayram Farisoğulları: None declared, Levent Kılıç: None declared, Zeynep Saribas: None declared, Umut Kalyoncu Consultant of: Abbvie, Amgen, Janssen, Lilly, Novartis, UCB, Ali Akdoğan: None declared, Burcin Sener: None declared, Şule Apraş Bilgen: None declared, Omer Karadag: None declared

DOI: 10.1136/annrheumdis-2020-eular.6437

\section{AB0629 \\ VASCULAR MANIFESTATIONS OF SYSTEMIC SCLEROSIS: SIMILAR IN PATHOGENESIS, DIFFERENT IN FREQUENCY}

N. Yudkina ${ }^{1}$, A. Volkov ${ }^{2}$, E. Nikolaeva ${ }^{2}$, E. Nasonov ${ }^{2,2}$. ${ }^{1}$ V.A. Nasonova Research Institute of Rheumatology, Moscow, Russian Federation; ${ }^{1}$ V.A.Nasonova Research Institute of Rheumatology, Moscow, Russian Federation

Background: Pulmonary arterial hypertension (PAH) is one of the main manifestations of vascular involvement in systemic sclerosis (SSc). The association of PAH with Raynaud's phenomenon (RP) and digital ischemic disorders is assumed.

Objectives: The aim of the study to detect of the possible relationship of pathogenetically similar processes and the predictor role in the early diagnosis of $\mathrm{PAH}$ and digital ischemic disorders by the nailfold videocapillaroscopy (NVC).

Methods: 111 patients with SSc (51 patients with PAH (SSc-PAH) and 60 patients without $\mathrm{PAH}$ ) include in this study. In all patients, the diagnosis of SSc was validated according to the 2013 ACR-EULAR criteria. PAH was diagnosed by right heart catheterization. NVC was performed in all recruited subjects. Capillary quantitative parameters (loops length and width, capillary density, neoangiogenesis) were evaluated and a semi-quantitative scoring was used (specific patterns - early, active and late) to define microvascular alterations. The test evaluated the presence of capillaroscopic changes in the nailfold bed on 2-5 fingers of both hands. The normal capillaroscopic pattern was characterized by the presence of 7-11 capillaries in the form of hairpins per $1 \mathrm{~mm}$. Pathological patterns were characterized by morphological and structural changes, such as expanded and giant capillaries, hemorrhages, avascular fields, neoangiogenesis. The capillaroscopy pattern (normal, non-specific, early/active/late) was determined qualitatively. Decreased capillary density, dilated, giant or branched capillaries, microhemorrhages were evaluated semi-quantitatively.

Results: RP was detected in $100 \%$ of cases in both groups. In the analysis of capillaroscopic patterns in both groups, the early and late scleroderma types of changes prevailed, but no significant differences were noted. Typical scleroderma patterns were found in 51 patients (100\%) with SSc-PAH. In 3 patient with SSc without $\mathrm{PAH}$, the abnormalities were regarded as non-specific. The NVC pattern was detected to be early in 8 patients with SSc-PAH and in 11 with SSc without PAH. The NVC pattern was found to be active in 16 patients with SSc-PAH and in 18 with SSc without PAH. The NVC pattern was detected to be late in 27 patients with SSc-PAH and in 28 with SSc without $\mathrm{PAH}$. In addition to $\mathrm{RP}$, the development of digital ulcers was noted with equal frequency in history (25 patients with SSc-PAH and 32 with SSc without PAH). Also, the time to their appearance from the first symptom of SSc was the same $(56(16 ; 84)$ months and $44(23 ; 72)$ months, respectively). Severe forms of digital ischemic disor ders were observed rarely and with the same frequency in the studied groups. Ischemia in 2 patients with SSc-PAH and in 5 patients with SSc without PAH, gangrene in 2 patients only in the SSc group without $\mathrm{PAH}$, amputation in 1 of each group.

Conclusion: In the course of the study, it was not possible to identify differences between the NVC patterns, the frequency and severity of digital ischemic disorders in the compared groups. That fact does not allow using the NVC as an early diagnosis of PAH in SSc. However, the NVC can help predict the development of digital ischemic disorders.

References: No

Disclosure of Interests: None declared

DOI: 10.1136/annrheumdis-2020-eular.6656

\section{AB0630 \\ IMBALANCE BETWEEN TH17 AND REGULATORY T CELLS IN PATIENTS WITH PM/DM COMBINED WITH EBV/CMV VIRAEMIA}

X. Zheng ${ }^{1}$, R. Su${ }^{1}$, Y. Liu ${ }^{1}$, X. Li ${ }^{1}$, C. Wang2. ${ }^{1}$ The Second Hospital of Shanxi Medical University, Department of Rheumatology, Tai Yuan, China; ${ }^{1}$ The Second Hospital of Shanxi Medical University, Department of Rheumatology, Tai Yuan, China

Background: Dermatomyositis and polymyositis (DM/PM) are associated with muscle weakness and inflammatory infiltration within the skeletal muscle. The numerical and functional defects of immune cells, due to long-term uses of glucocorticoids and disease-modifying anti-rheumatic drugs (DMARDs) together with immune disturbances associated with disease itself, lead to high risks in opportunistic infections, such as Epstein-Barr virus (EBV) and cytomegalovirus $(\mathrm{CMV}){ }^{1-2}$ We want to observe changes of peripheral lymphcytessubsets in $\mathrm{PM} /$ DM patients with EBV and/or CMV infection,especially whether there is imblance between Th17 and Treg cells.

Objectives: To investigate the characteristics of peripheral lymphocyte subsets in PM/DM with EBV and/or CMV infection, especially the Th17 and Treg cells.

Methods: From February 2016 to November 2019, PM/DM patients with EBV and/or CMV viremia (infection group, $\mathrm{n}=34$ ) and without infection (non-infection group, $n=31)$ as well as healthy adult controls $(n=20)$ were enrolled in our study. Absolute numbers of total T, total B, NK, CD4 + T, CD8 + T cells, and CD4 + T subsets (Th1, Th2, Th17 and Treg cells) in peripheral blood by flow cytometry combined with standard absolute counting beads.

Results: (1) Compared with PM/DM patients without infection, 34 PM/DM patients with EBV and/or CMV infection, including 12 patients with EBV, 20 patients with $\mathrm{CMV}, 2$ patients combined $\mathrm{EBV}$ and $\mathrm{CMV}$, the absolute number of total T lymph cells $(P=0.019)$, total $B$ lymph cells $(P=0.037)$, NK cells $(P=0.033)$, CD4 + T cells $(P=0.000)$, Th1 cells $(P=0.014)$, Th2 cells $(P=0.003)$, Th17 cells $(P=0.003)$, Treg cells $(P=0.004)$ lower than its of $(P=0.003)$ patients without infection, the absolute number of $\mathrm{CD} 8+\mathrm{T}$ cells $(\mathrm{P}=0.427)$ has no obvious difference between them.

(2) And its the absolute number of total $T$ lymph cells $(P=0.000)$, total $B$ lymph cells $(P=0.003)$, NK cells $(P=0.000), C D 4+T$ cells $(P=0.000), C D 8+T$ cells $(P=0.006)$, Th1 cells $(P=0.000)$, Th2 cells $(P=0.001)$, Th17 cells $(P=0.000)$ and Treg cells $(\mathrm{P}=0.000)$ significantly lower than healthy control.

(3) Compared with the healthy control,the absolute number of total $\mathrm{T}$ lymph cells $(P=0.000)$, NK cells $(P=0.000), C D 4+T$ cells $(P=0.031), C D 8+T$ cells $(P=0.000)$, Th1 cells $(P=0.002)$, Th2 cells $(P=0.031)$, and Treg cells $(P=0.000)$ in $\mathrm{PM} / \mathrm{DM}$ without infection evidently lower, but there is no siginificant difference in absolute number of total $B$ lymph cells $(P=0.19)$ and Th17 cells $(P=0.171)$.

Conclusion: We show that the absolute number of peripheral blood lymphocytes and CD4+T subsets in patients with PM/DM with EBV and/or CMV viremia is further reduced. In addition to Treg cells, a decrease in Th17 cells may also be an important feature of EBV and/or CMV infection in DM/PM. These cell reductions may be the cause and risk indicator of viral infections.

References:

[1] Yang X, Hao Y, Zhang X, et al. Mortality of Chinese patients with polymyositis and dermatomyositis. Clin Rheumatol. 2020 Jan 4. doi: 10.1007/s10067-01904910-w. [Epub ahead of print]. PMID: 31902027

[2] Matsushita T,Kobayashi T, Kano M, et al. Elevated serum B-cell activating factor levels in patients with dermatomyositis: Association with interstitia lung disease. J Dermatol.2019:46:1190-6. doi:10.1111/1346-8138.15117 


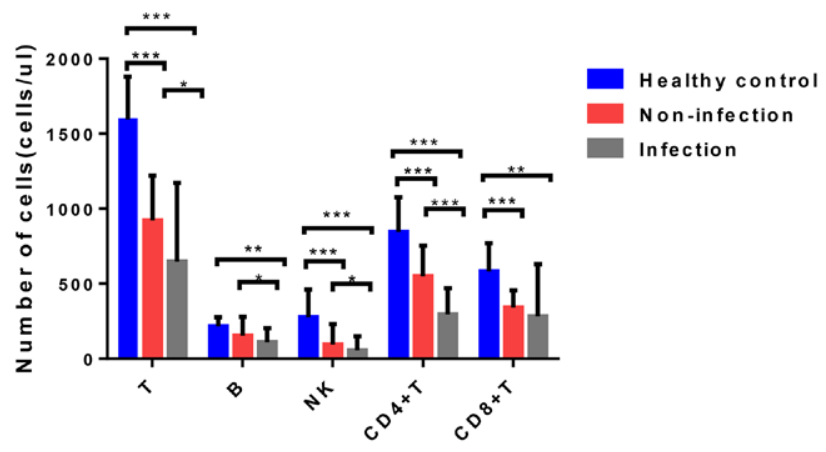

B

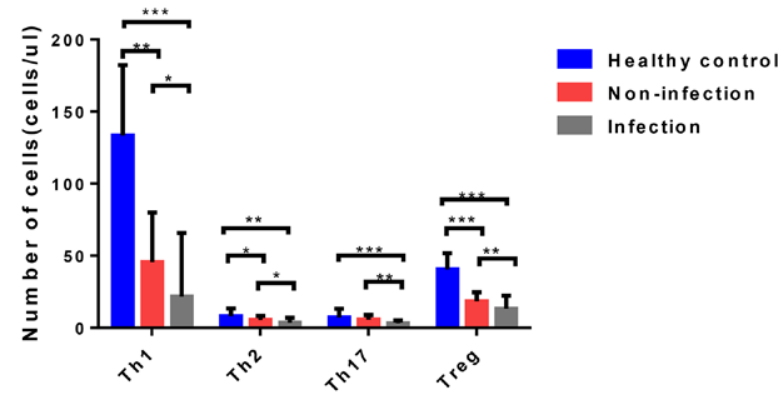

Figure. Absolute numbers of peripheral lymphocyte subsets between healthy controls and patients were assessed by fow cytometry using oneplatform method. PM/DM infection group $(n=34), P M / D M n$ non- infection group $(n=31)$ and healthy control group $(n=20) .\left({ }^{*} p<0.05\right.$, $\left.{ }^{\star *} p<0.01,{ }^{\star \star *} p<0.001\right)$

Disclosure of Interests: None declared

DOI: 10.1136/annrheumdis-2020-eular.5163

\section{AB0631 THE CLINICAL CHARACTERISTICS OF SYSTEMIC SCLEROSIS WITH LUNG CANCER: DATA FROM SINGLE CENTER IN CHINA}

H. Zhong ${ }^{1}$, J. Zhou ${ }^{1}$, S. Zhang ${ }^{1}$, Y. Xu ${ }^{2}$, Y. Hou ${ }^{1}$, M. Li ${ }^{1}$, D. Xu ${ }^{1}$, M. Wang ${ }^{2}$, X. Zeng ${ }^{1}{ }^{1}$ Peking Union Medical College Hospital, Chinese Academy of Medical Sciences, Department of Rheumatology, Beijing, China; ${ }^{2}$ Peking Union Medical College Hospital, Chinese Academy of Medical Sciences, Department of Respiration, Beijing, China

Background: Malignant neoplasms is the second most common non-SSc associated cause of death in SSc patients, only second to infection. And among all the neoplasms, lung cancers are the most common, which is in the urgent need of attention from clinicians.

Objectives: To analyze the clinical features of patients of SSc with lung cancer Methods: Medical records of inpatients admitted in Peking Union Medical College Hospital from March 1992 to December 2018, were collected and analyzed, including the clinical manifestation, laboratory data, radiological images, pathology. SSc patients without lung cancer during the same period, matched by age and gender, were selected as the controls.

Results: Nineteen SSc patients with complete medical records were identified, with $17(89.5 \%)$ females and $2(10.5 \%)$ males. The mean age of SSc onset was $37.8 \pm 12.0)$ years old and of lung cancer diagnosis was $(54.4 \pm 10.2)$ years old. One $(5.3 \%)$ had a smoking history. Eight $(42.1 \%)$ patients had family history of cancer, which was significantly higher than those without lung cancer (4 patients, 5.3\%, $\mathrm{P}<0.001$ ). The proportion of limited cutaneous SSc (ICSSc) were $63.2 \%$ among these patients, and $18(94.7 \%)$ had interstitial lung disease (ILD), the difference between the two groups was not statistically significant $(P=0.259$ and 0.051 , respectively). All ILD was diagnosed before the onset of lung cancer, with a median interval of 9.2 (range 1.6-28.1) years. SSc patients with lung cancer had less myositis than control group ( $0 \%$ vs. $27.6 \%, P=0.032$ ), yet no significant differences were identified in Raynaud's syndrome, esophageal involvement, digital ulcers, pulmonary hypertension, telangiectasia and arthritis. All patients developed lung cancer after the diagnosis of SSc, with a median interval 10.5 (range 2.0-36.2) years. In most of them(18, 94.7\%), lung cancer happened after at least 6 years of SSc onset. Newly happened cough (9 patients), worsening decrease in activity endurance (3), chest pain (2), hemoptysis (2), nodes in lung through regular CT scans (3) were the first presentations of lung cancer. Ten(62.5\%) neoplasms developed in the lower lobes of the lung, while 3 was in the upper lobes, one in the lingual lobe, and one in the left pulmonary hilum, and 3 were unknown. The median survival of the case group were 31.4 years, while the median survival of the control group was not reached. Eight patients tested EGFR gene mutation or ALK gene rearrangement, and only 2 were positive.

Conclusion: It is not uncommon that SSc could be concomitant with lung cancer, especially for those with long disease duration and family history of malignancy. Due to the subtle onset of lung cancer, clinicians should pay attention to it during clinical practice.

References:

[1] Hu S et al. Arthritis Res Ther, 2018, 20:235.

[2] Steen VD, Ann Rheum Dis, 2007, 66:940-944.

[3] Tyndall AJ et al. Ann Rheum Dis, 2010, 69:1809-1815.

[4] Compton CC et al. AJCC Cancer Staging Atlas [M].7th ed. New York:Springer, 2012:311-328.

[5] Detterbeck FC et al. Chest, 2016, 1:193-203.

[6] Kuo CF et al. J Rheumatol, 2012, 41:44-49.

[7] Nishioka K et al. J Dermatol, 1996, 23:677-682.

[8] Ling Z, et al. 2016, 10:238-241.

[9] Heist RS et al. J Thorac Oncol, 2012, 7:1775-1780.

[10] Kim HR et al. J Clin Oncol, 2013, 31:731-737.

[11] Igusa T et al. Ann Rheum Dis, 2018, 77:1179-1186.

[12] Hill CL et al. Lancet, 2001, 357:96-100.

[13] Pontifex EK et al. Ann Rheum Dis, 2007, 66:551-553.

[14] Thun MJ et al. N Engl J Med, 2013, 368:351-364.

Disclosure of Interests: Hui Zhong: None declared, Jiaxin Zhou: None declared, Shangzhu Zhang: None declared, Yan Xu: None declared, Yong Hou: None declared, Mengtao Li: None declared, Dong Xu: None declared, Mengzhao Wang: None declared, Xiaofeng Zeng Consultant of: MSD Pharmaceuticals DOI: 10.1136/annrheumdis-2020-eular.3423

\section{Spondyloarthritis - treatment}

\begin{tabular}{l|l}
\hline AB0632 & EFFECTIVENESS OF ETANERCEPT BIOSIMILARS \\
IN REACTIVE ARTHRITIS: RETROSPECTIVE CASE \\
CONTROL
\end{tabular}

S. Ahmed ${ }^{1}$, P. Padhan ${ }^{1} .{ }^{1}$ Kalinga Institute of Medical Sciences (KIMS), Bhubaneswar, India

Background: There is a paucity of evidence based therapies for reactive arthritis $(\operatorname{ReA})$. Data is limited for anti-TNF drugs usage [Table 1] with even less data on biosimilars.

Table 1. Anti-TNF use in reactive arthritis

\begin{tabular}{|c|c|c|c|c|}
\hline Place (year) & Anti-TNF & $\mathrm{N}$ & Outcomes & Remarks \\
\hline $\begin{array}{l}\text { Pennsylvania, } \\
\text { USA (2005) }\end{array}$ & Etanercept & 16 & $\begin{array}{l}10 \text { completed trial: } 9 \\
\text { responders }\end{array}$ & $\begin{array}{l}\text { Synovial histology } \\
\text { improvement but } \\
\text { not normalized }\end{array}$ \\
\hline $\begin{array}{l}\text { Strasbourg, } \\
\text { France (2011) }\end{array}$ & $\begin{array}{l}\text { Infliximab(5) } \\
\text { Etanercept(4) } \\
\text { Adalimumab(1) }\end{array}$ & 10 & $\begin{array}{l}\text { Rapidly effective in } 9 \\
\text { patients }(90 \%) \\
5 \text { had DFR }\end{array}$ & $\begin{array}{l}\text { Relapses responded } \\
\text { to re- initiation }\end{array}$ \\
\hline $\begin{array}{l}\text { Besançon, } \\
\text { France (2016) }\end{array}$ & $\begin{array}{l}\text { Etanercept (9) infliximab } \\
\text { (3) Adalimumab(3) }\end{array}$ & 15 & 5 had DFR & $\begin{array}{l}9 \text { developed chronic } \\
\text { SpA }\end{array}$ \\
\hline $\begin{array}{l}\text { Delhi, India } \\
\text { (2019) }\end{array}$ & $\begin{array}{l}\text { Infliximab(10), } \\
\text { Adalimumab(3) } \\
\text { Etanercept(1) }\end{array}$ & 9 & $\begin{array}{l}\text { At median of } 3.5 \\
\text { months: } 4 \text { had } \\
\text { remission, } 3 \text { relapse, } \\
1 \text { adverse reaction }\end{array}$ & $\begin{array}{l}\text { Biologicals were not } \\
\text { given regularly }\end{array}$ \\
\hline Current study & Etanercept biosimilars & 10 & $\begin{array}{l}\text { At median } 7 \text { months: } \\
6 \text { had DFR }\end{array}$ & $\begin{array}{l}\text { All patients } \\
\text { responded }\end{array}$ \\
\hline
\end{tabular}

DFR: drug free remission

Objectives: To find out the outcomes of etanercept biosimilars (ETN-b) use in $\operatorname{ReA}$

Methods: A retrospective review of patients meeting the Braun criteria ${ }^{5}$ for probable ReA helped identify patients on ETN-b. Patients with less than 1 year follow-up and those who had received less than 5 doses of ETN were excluded. Biological naïve patients who had completed at least 1 year follow-up were included as controls. Baseline and current status was compared between these two groups. Results: Of 94 identified ReA patients, 11(11.7\%) had received ETN-b and 10 met the case definition. Five each had received one of two ETN-b. 30 were available as controls. All cases had been documented as refractory ReA. Amongst cases, 7 patients had resolution of $\mathrm{ReA} ; 2$ had relapsing courses and 1 persistent arthritis. Four were in remission off all drugs. Controls has similar proportions [Table 2]. There were no infections or adverse effects recorded during follow-up. 